\title{
PENERAPAN MODEL PEMBELAJARAN BERBASIS MASALAH (PBM) UNTUK MENINGKATKAN HASIL BELAJAR MATEMATIKA SISWA KELAS V SDN 30 PEKANBARU
}

\author{
Marissa Andarini ${ }^{{ }^{*}}$, Gustimal Witri ${ }^{1}$, M. Jaya Adi Putra ${ }^{1}$ \\ ${ }^{1}$ Program Studi Pendidikan Guru Sekolah Dasar, Fakultas Keguruan dan IImu \\ Pendidikan, Universitas Riau, Pekanbaru, Indonesia \\ aisyahdindaa02@gmail.com
}

Received: March $08^{\text {th }}, 2020$

Revised: August $21^{\text {st }}, 2020$

Accepted: August $24^{\text {th }}, 2020$

\begin{abstract}
The background of this research is that there are several symptoms in the process of learning mathematics, namely: 1) passive / inactive students are characterized by the absence of questions after the teacher explains. 2) the number of noisy students is seen from the number of students who walk to see the assignment exercises given by the teacher. 3) the number of students who do not understand and understand is seen from the number of students who repeatedly ask when given practice. This research is a classroom action research that aims to improve student mathematics learning outcomes by applying problem-based learning models. This research was conducted in class V SDN 30 Pekanbaru. Data collection instruments in this thesis are teacher and student activity sheets and student learning outcomes assessment sheets. This thesis presents preliminary data before applying the problem-based learning model (PBM) which is 79.17 and increased to 83.04 in the first cycle and increased again to 92.60. Teacher activity also increased at each meeting, namely $65 \%$ with a good category in the first cycle the first meeting increased to $70 \%$ with a good category. In the second cycle also increased to $90 \%$ with a very good category at the first meeting and increased to $95 \%$ with a very good category at the second meeting. In the results of this study student learning outcomes have increased after applying the problem-based learning model (PBM) marked by an increase in teacher and student activities in each cycle. The results of this study prove that the problem-based learning model can improve mathematics learning outcomes of fifth grade students of SDN 30 Pekanbaru.
\end{abstract}

Keyword: learning results; mathematics; problem based learning model.

\section{PENDAHULUAN}

Matematika merupakan ilmu dasar yang sudah menjadi alat untuk mempelajari ilmu-ilmu yang lain. Oleh karna itu penguasaan terhadap matematika mutlak diperlukan dan konsep-konsep matematika harus dipahami dengan benar sejak dini. 
Matematika merupakan sebuah ilmu dedukatif, aksiomatik, formal, hirarkis, abstrak dan bahasa simbol yang padat arti dan semacamnya adalah sebuah sistem matematika. Sistem matematika berisikan model-model yang dapat digunakan untuk mengatasi persoalan-persoalan nyata.

Keberhasilan dalam belajar matematika ditentukan oleh dua faktor, yaitu: internal dan eksternal. Yang mana faktor internal adalah yang ada dalam diri sendiri. Sedangkan eksternal adalah faktor dari luar diri seperti dari guru dan lingkungan sekitar. Guru memiliki peran yang penting dalam kesuksesan proses pembelajaran di sekolah dasar (Putra, 2019). Oleh karna itu peranan guru diharapkan dapat menyampaikan materi khususnya matematika secara menarik dan baik agar dapat membentuk siswa menjadi seorang yang aktif, kreatif dan punya daya serap yang tinggi dalam menerima pelajaran (Putra dkk, 2020).

Dari hasil wawancara dengan guru kelas V SDN 30 Pekanbaru diketahui bahwa hasil belajar matematika kelas $V$ SDN 30 masih kurang dan belum memuaskan. Hal ini dapat dilihat pada tabel 1.

Tabel 1 hasil belajar matematika kelas V SDN 30 Pekanbaru

\begin{tabular}{ccccc}
\hline $\begin{array}{c}\text { Jumlah } \\
\text { Siswa }\end{array}$ & KKM & $\begin{array}{c}\text { Jumlah Siswa } \\
\text { Tuntas }\end{array}$ & $\begin{array}{c}\text { Jumlah Siswa } \\
\text { Tidak Tuntas }\end{array}$ & Rata-Rata \\
\hline 23 & 78 & $12(52,17 \%)$ & $11(47,82 \%)$ & 79,17 \\
\hline
\end{tabular}

Dari tabel 1, tampak masih cukup rendahnya hasil belajar matematika siswa kelas V SDN 30 Pekanbaru, maka salah satu upaya yang harus dilakukan adalah variasi dalam proses pembelajaran dengan implementasi model pembelajaran matematika.

Salah satu model pembelajaran yang dapat diterapkan untuk meningkatkan hasil belajar matematika siswa yaitu model pembelajaran berdasarkan masalah. Model ini terbukti mampu meningkatkan hasil belajar matematika (Fendrik \& Elvina, 2018; Yenny dkk, 2020) dan juga hasil belajar bidang studi lainnya (Lestari dkk, 2017; Maisya dkk, 2020). Menurut peneliti sebelumnya Lestari dkk. (2017) model Pembelajaran Berbasis Masalah diterapkan pada mata pelajaran IPS, 
menunjukan hasil yang meningkat. Oleh karena itu berdasarkan tabel diatas, peneliti melakukan penelitian dengan menggunakan model Pembelajaran Berbasis Masalah pada mata pelajaran Matematika. Diharapkan dengan menggunakan model pembelajaran berbasis masalah (PBM) dapat meningkatkan hasil belajar matematika siswa. Kelebihan dari penggunaan masalah dalam proses pembelajaran yaitu dengan lebih nyatanya serta konkritnya hasil yang didapat sehingga materi tersebut mudah untuk dipahami dan diserap oleh siswa/i terutama pada kelas tinggi.

Atas dasar latar belakang tersebut, peneliti ingin melakukan penelitian dengan judul "Penerapan Model Pembelajaran Berbasis Masalah (PBM) untuk Meningkatkan Hasil Belajar Matematika Siswa Kelas V SDN 30 Pekanbaru" Metode penelitian.

\section{METODE PENELIAN}

Peneliti melaksanakan penelitian di SDN 30 Pekanbaru pada semester ganjil tahun ajaran 2019/2020. Penelitian ini dilakukan pada bulan November 2019. Desain penellitian yang digunakan yaitu Penelitian Tindakan Kelas (PTK). Menurut Aqib dkk. (2011) PTK yaitu penelitian yang dilakukan oleh guru dikelasnya sendiri dengan cara merencanakan, melaksanakan, mengamati dan merefleksikan tindakan secara kolaboratif dan partisipatif dengan tujuan perbaiki kinerja sebagai guru, sehingga hasil belajar siswa dapat meningkat.

Subjek penelitian ini adalah siswa kelas $\mathrm{V}$ yang berjumlah 23 orang dengan 12 siswa laki-laki dan 11 orang siswa perempuan. Instrument yang digunakan dalam penelitian ini adalah perangkat pembelajaran yang terdiri dari silabus, rencana pelaksanaan pembelajaran (RPP), lembar kerja peserta didik (LKPD), dan lembar evaluasi. Kemudian instrument pengumpulan data terdiri dari lembar observasi dan lembar ulangan harian. Teknik pengumpulan data yang digunakan dalam penelitian ini adalah teknik observasi, teknik tes dan dokumentasi.

Data yang diperoleh dari penelitian ini dianalisis dengan menggunakan statistika deskriptif. Adapun proses pelaksanaannya dimulai dari penghimpunan data, menyusun atau mengatur data, menyajikan data dan menganalisis data 
angka guna memberikan gambaran tentang sesudah gejala, peristiwa atau keadaan.

Analisis aktivitas guru dan siswa dihitung dengan menggunakan rumus berikut ini:

$$
\text { Nilai }=\frac{\text { Skoryangdiperoleh }}{\text { Skormaksimum }} \times 100 \% \text { (Purwanto, 2010:207) }
$$

Untuk mengetahui aktivitas guru dan siswa dianalisis dengan menggunakan kriteria yang disajikan pada tabel 2 .

Tabel 2. Kategori aktivitas guru dan siswa

\begin{tabular}{c|c}
\hline Tingkat Penguasaan & Bobot Kualitas \\
\hline $85-100 \%$ & Sangat baik \\
$65-84 \%$ & Baik \\
$55-64 \%$ & Cukup \\
$0-54 \%$ & Kurang \\
\hline
\end{tabular}

Siswa dikatakan tuntas apabila telah mencapai KKM sebesar 78 yang telah ditetapkan oleh sekolah. Nilai yang diperoleh siswa dihitung dengan rumus berikut ini:

$$
\mathrm{S}=\frac{R}{N} \times 100(\text { Purwanto, 2010:112) }
$$

Keterangan :

$S$ :Nilai yang diperoleh (dicari).

$\mathrm{R}$ :Jumlah skor dari item atau soal yang dijawab benar.

$\mathrm{N}$ :Skor maksimum dari tes tersebut.

Untuk mengetahui rata-rata kelas dapat menggunakan rumus :

$$
\bar{x}=\frac{\sum X}{N}(\text { Sudjana, 2014:109) }
$$


Keterangan :

$\bar{x} \quad$ : Nilai rata-rata kelas

$\Sigma X$ :Jumlah semua nilai siswa

$\mathrm{N}$ :Jumlah siswa

Kelas dikatakan tuntas jika $75 \%$ siswa tuntas dari seluruh siswa memperoleh nilai 80. Adapun rumus ketuntasan belajar sebagai berikut:

$$
\mathrm{Kb}=\frac{T}{T t} \times 100 \% \text { (Trianto, 2009:241) }
$$

Keterangan :

$\mathrm{Kb}$ : Ketuntasan belajar siswa

$T$ : Jumlah siswa yang tuntas

$\mathrm{Tt}$ : Jumlah siswa seluruhnya

Untuk mengetahui peningkatan hasil belajar siswa kelas V SDN 30 Pekanbaru dengan menerapkan model pembelajaran berbasis masalah dirumuskan dengan:

$$
\mathrm{P}=\frac{\text { Postrate }- \text { Bastrate }}{\text { Bastrate }} \times 100 \% \text { (Aqib, dkk, 2011:53) }
$$

Keterangan :

P : :Persentase peningkatan

Postrate :Nilai sudah diberi tindakan

Basrate :Nilai sebelum tindakan 


\section{HASIL PENELITIAN}

Penelitian tindakan kelas ini dilaksanakan di kelas Va SDN 30 Pekanbaru dengan jumlah siswa 23 orang terdiri dari 13 siswa laki-laki dan 10 siswa perempuan. Penelitian ini dilakukan sebanyak 2 siklus. Siklus I terdiri dari 2x pertemuan dan 1x UH dengan materi pembelajaran jarak dan debit. Dan siklus ke II terdiri dari 2x pertemuan dan 1x UH dengan materi pembelajarannya denah dan titik koordinat. Setiap pertemuan dilaksanakan dalam 1 jam pelajaran x 3 jam sesuai dengan jadwal pembelajaran.

Setiap kegiatan pembelajaran dilaksanakan dengan model pembelajaran berbasis masalah yang didukung dengan lembar kerja peserta didik. Sebelum siklus I pertemuan pertama dimulai peneliti mencari nilai ulangan harian(UH) sebelumnya dari peserta didik untuk dijadikan sebagai data awal untuk melakukan penelitian lanjutan. Data awal dari nilai ulangan harian (UH) sebelumnya dijadikan sebagai perbandingan hasil belajar sebelum dan sesudah penerapan model pembelajaran berbasis masalah (PBM).

Pada setiap akhir siklus I dan II diadakan ulangan harian (UH) yang hasilnya dipakai sebagai landasan untuk melakukan siklus berikutnya. Setiap pertemuan observer mengamati aktivitas guru dan siswa selama pelaksanaan kegiatan belajar dan mengajar menggunakan model pembelajaran berbasis masalah berlangsung dengan menggunakan lembar observasi.

Pada siklus I pertemuan ke II materi pembelajaran debit, diawali dengan menyiapkan siswa untuk belajar dengan cara berdoa sebelum belajar dan mengajak siswa untuk duduk dengan rapi. Setelah itu guru menyajikan masalah sederhana yang berkaitan dengan materi Debit yaitu dengan menyajikan media pembelajaran berupa ember berisi air dan gelas atau wadah kosong. Lalu guru membagikan Lembar Kerja Peserta Didik atau LKPD dan mengajak siswa untuk memperhatikan langkah-langkah kegiatan yang ada dalam LKPD. Guru membimbing siswa untuk mengerjakan atau memperagakan kegiatan sesuai dengan langkah-langkah dalam LKPD dengan cara berkelompok yang terdiri dari4-5 siswa. Lalu guru meminta siswa ntuk menyajikan hasil kerja kelompok didepan kelas. Setelah semua kelompok menyajikan hasil kerja kelompoknya, 
guru membagikan lembar evaluasi kepada setiap anak. Dan guru menutup pembelajaran dengan membuat kesimpulan bersama siswa dan diakhiri dengan doa bersama.

\section{Aktivitas Guru dan Siswa}

Aktivitas guru selama proses pembelajaran berlangsung dapat diketahui melalui lembar observasi yang sudah diisi oleh observer, data aktivitas guru pada siklus I dan siklus II selama proses pembelajaran berbasis masalah dikelas V SDN 30 Pekanbaru tahun ajaran 2019/2020. Aktivitas guru pada siklus I dan II disajikan pada tabel 3 berikut ini:

Tabel 3. aktivitas guru pada siklus I dan siklus II

\begin{tabular}{ccccc}
\hline Siklus & Pertemuan & Jumlah & Persentase & Kategori \\
\hline I & Pertemuan 1 & 10 & $65 \%$ & Baik \\
& Pertemuan 2 & 13 & $70 \%$ & Baik \\
II & Pertemuan 1 & 17 & $90 \%$ & Sangat Baik \\
& Pertemuan 2 & 18 & $95 \%$ & Sangat Baik \\
\hline
\end{tabular}

Berdasarkan tabel 3 dapat disimpulkan bahwa aktivitas guru pada tiap pertemuan mendapat kenaikan yang menandakan bahwa guru semakin baik dalam menguasai kelas dengan menggunakan model pembelajaran berbasis masalah (PBM) dari tiap-tiap pertemuan.

Tabel 4 aktivitas siswa siklus I dan siklus II

\begin{tabular}{ccccc}
\hline Siklus & Pertemuan & Jumlah & Persentase & Kategori \\
\hline I & Pertemuan 1 & 10 & $50 \%$ & Kurang \\
& Pertemuan 2 & 13 & $65 \%$ & Baik \\
II & Pertemuan 1 & 17 & $85 \%$ & Sangat Baik \\
& Pertemuan 2 & 18 & $90 \%$ & Sangat Baik \\
\hline
\end{tabular}


Tabel 4 menyajikan aktivitas siswa pada tiap pertemuan. Aktivitas siswa mengalami peningkatan yang menandakan bahwa siswa semakin baik dalam proses pembelajaran menggunakan model pembelajaran berbasis masalah (PBM) dari tiap-tiap pertemuan.

\section{Hasil Belajar}

Dari hasil belajar siswa dengan Penerapan Model Pembelajaran Berbasis Masalah (PBM) Untuk Meningkatkan Hasil Belajar Matematika Siswa Kelas V SDN 30 Pekanbaru, dilakukan pengukuran hasil belajar yang diambil dari skor dasar, ulangan harian siklus I, ulangan harian siklus II dapat dilihat pada tabel 5 . berikut ini:

Tabel 5. Nilai rata-rata kelas

\begin{tabular}{ccc}
\hline Pertemuan & Jumlah Siswa & Rata-rata \\
\hline Skor Dasar & 23 Orang & 79,17 \\
Siklus I & 23 Orang & 83,04 \\
Siklus II & 23 Orang & 92,60 \\
\hline
\end{tabular}

Tujuan penelitian ini adalah untuk meningkatkan hasil belajar matematika siswa setelah diadakannnya tindakan dengan cara membandingkan dengan skor dasar. Peningkatan hasil belajar siswa dapat dilihat pada tabel 6 berikut:

Tabel 6. Peningkatan hasil belajar siswa sebelum dan sesudah tindakan

\begin{tabular}{cccc}
\hline Data & Jumlah Siswa & $\begin{array}{c}\text { Rata-Rata Hasil } \\
\text { Belajar }\end{array}$ & $\begin{array}{c}\text { Persentase Peningkatan } \\
\text { Hasil Belajar }\end{array}$ \\
\hline SkorDasar & 23 Orang & 79,17 & \\
UH I & 23 Orang & 83,04 & $3.87(4 \%)$ \\
UH II & 23 Orang & 92,60 & $13,43(16 \%)$ \\
\hline
\end{tabular}




\section{Ketuntasan Belajar Siswa}

Ketuntasan belajar siswa pada siklus I dan siklus II dengan menggunakan model pembelajaran berbasis masalah yang terdiri dari ketuntasan individu dan ketuntasan klasikal dapat dilihat pada tabel 7 berikut:

Tabel 7. Ketuntasan belajar siswa

\begin{tabular}{|c|c|c|c|c|c|}
\hline \multirow{2}{*}{ Data } & \multirow{2}{*}{$\begin{array}{c}\text { Jumlah } \\
\text { Siswa }\end{array}$} & \multirow{2}{*}{$\mathrm{KKM}$} & \multicolumn{2}{|c|}{ KetuntasanIndividu } & \multirow{2}{*}{ Klasikal } \\
\hline & & & Tuntas & TidakTuntas & \\
\hline Skor & 23 & \multirow{2}{*}{78} & 12 Orang & 11 & Tidak \\
\hline Dasar & Orang & & $(52 \%)$ & Orang $(47 \%)$ & Tuntas \\
\hline \multirow{2}{*}{ UH I } & 23 & \multirow{2}{*}{78} & 16 Orang & 7 & Tidak \\
\hline & Orang & & $(69 \%)$ & Orang (30\%) & Tuntas \\
\hline \multirow{2}{*}{ UH II } & 23 & \multirow{2}{*}{78} & 21 Orang & 0 & Tunton \\
\hline & Orang & & $(91 \%)$ & $2 \mathrm{Cranly}(0 \%)$ & tumas \\
\hline
\end{tabular}

\section{PEMBAHASAN HA}

Berdasarkan hasil penelitian yang peneliti lakukan melalui dua siklus ditemukan bahwa Model Pembelajaran Berbasis Masalah (PBM) dapat meningkatkan hasil belajar matematika siswa kelas V SDN 30 Pekanbaru. Hal ini dapat ditunjukan dari nilai rata-rata kelas, mulai dari sebelum diberikan tindakan yaitu model pembelajaran berbasis masalah (PBM) adalah 79,17 menjadi 83,04 pada siklus I dengan persentase peningkatan hasil belajar sebesar 3,87 (4\%). Dan meningkat lagi menjadi 92,60 pada siklus II dengan persentase peningkatan hasil belajar sebesar 13,43 (16\%).

Berdasarkan data diatas dapat membuktikan bahwa model pembelajaran berbasis masalah dapat meningkatkan hasil belajar matematika siswa kelas $\mathrm{V}$ SDN 30 Pekanbaru. Hal ini sejalan dengan penelitian yang dilakukan oleh Siti Lestari dkk. (2017) yaitupenerapan model pembelajaran berbasis masalah untuk meningkatkan hasil belajar ipssiswa kelas IV SD Babussalam Pekanbaru.

Model pembelajaran berbasis masalah (PBM) dapat meningkatkan hasil belajar siswa terlepas dari mata pelajaran apapun. Karena model pembelajaran 
berbasis masalah menuntut siswa untuk aktif dalam belajar dan mengasah kemampuan berpikir kritis dan berpikir tingkat tinggi. Jika pada penelitian sebelumnya peneliti sebelumnya mencoba pada mata pelajaran IPS, dan terdapat peningkatan hasil belajar dan penelitian sekarang mencoba pada mata pelajaran matematika. Dan pada mata pelajaran matematika, hasil belajar siswa mengalami peningkatan. Hal ini membuktikan bahwa terlepas dari mata pelajaran, model pembelajaaran berbasis masalah dapat meningkatkan hasil belajar siswa.

Disimpulkan bahwa dengan menerapan model pembelajaran berbasis masalah dapat meningkatkan hasil belajar matematika siswa. Jadi pada analisis data, pada ketuntasan belajar siswa secara klasikal dinyatakan tuntas karena mencapai $91 \%$ siswa tuntas pada siklus II. Dan menyatakan hipotesis diterima yang artinya penerapan model pembelajaran berbasis masalah dapat meningkatkan hasil belajar matematika siswa kelas V SDN 30 Pekanbaru.

\section{SIMPULAN}

Hasil belajar siswa pada rata-rata skor dasar atau sebelum penerapan pembelajaran berbasis masalah yaitu 79,17 mengalami peningkatan pada ulangan harian siklus I menjadi 83,04, jadi peningkatan skor dasar ke siklus I adalah sebesar 3.87 (4\%). pada ulangan harian siklus II rata-rata hasil belajar meningkat lagi menjadi 92,60, jadi peningkatan hasil belajar dari skor dasar ke siklus II sebesar 13,43 (16\%). Ketuntasan siswa secara klasikal juga mengalami peningkatan terlihat pada skor dasar jumlah siswa yang tuntas sebanyak 12 orang dan siswa yang tidak tuntas sebanyak 11 orang, pada siklus I jumlah siswa yang tuntas bertambah menjadi 16 orang, kemudian pada siklus II jumlah siswa yang tuntas bertambah menjadi 21 orang. 


\section{DAFTAR PUSTAKA}

Aqib, Z, dkk. (2011). Penelitian Tindakan Kelas untuk guru SMP,SMA,SMK. Bandung: CV. Yrama Widya.

Fendrik, M., \& Elvina, E. (2018). The Impact of Visual Thinking Approach to Promote Elementary Students' Problem Solving Skill in Mathemathics. Journal of Teaching and Learning in Elementary Education, 2(1), 98-108.

Lestari, S, dkk. (2017). Penerapan model pembelajaran berbasis masalah terhadap hasil belajar IPS siswa kelas IV SD Babusalam Pekanbaru. Journal Online Mahasiswa Fakultas Keguruan dan Ilmu Pendidikan, 5(1), 1-12.

Maisya, R., Hermita, N., Noviana, E., \& Alpusari, M. (2020). Implementasi Metode Outdoor Learning terhadap Complex Problem Solving Skills pada Mata Pelajaran IPA Siswa Kelas VA SDN 56 Pekanbaru. Tunjuk Ajar: Jurnal Penelitian IImu Pendidikan, 3(1), 22-32.

Purwanto. (2010). Evaluasi Hasil Belajar. Yogyakarta: Pustaka Pelajar.

Purwanto, N. (2010). Prinsip-prinsip dan Teknik Evaluasi Pengajaran. Bandung: PT Remaja Rosdakarya.

Putra, Z. H. (2019). Tantangan dan Peluang Guru SD dalam Pembelajaran Matematika Berbasis Teknologi Digital di Era Revolusi Industri 4.0. Prosiding Seminar Nasional Pendidikan Guru Sekolah Dasar Tahun 2019. Prodi PGSD FKIP UNRI.

Putra, Z. H., dkk. (2020). Workshop Pemanfaatan Lingkungan Belajar di Sekitar Sekolah dalam Pembelajaran Matematika bagi Guru Sekolah Dasar di Gugus IV Kecamatan Siak Hulu, Kampar. Jurnal Pengabdian Pada Masyarakat, 5(2), 475-486. https://doi.org/10.30653/002.202052.288

Sudjana, N. (2014). Penilaian Hasil Proses Belajar Mengajar. Bandung: PT Remaja Rosdikarya.

Trianto. (2009). Mendesain Model Pembelajaran Inovatif Progresif Konsep, Landasan, dan Implementasinya pada Kurikulum Tingkat Satuan Pendidikan (KTSP). Jakarta: Kencana Prenada Media Group.

Yenny, E., Fauzan, A., \& Fitria, Y. (2020). Improvement of Fifth Grade Students' Mathematical Reasoning and Learning Activity with the Implementation of Problem Solving Learning Model. Journal of Teaching and Learning in Elementary Education, 3(1), 132-141. 